\title{
Distinct GluN1 and GluN2 structural determinants for subunit-selective positive allosteric modulation of $N$-methyl- $D$-aspartate receptors
}

Katie L. Strong ${ }^{\text {a.b }}$, Matthew P. Epplin ${ }^{\mathrm{b}}$, Kevin K. Ogden ${ }^{\mathrm{a}}$, Pieter B. Burger ${ }^{\mathrm{b}}$, Thomas M. Kaiser ${ }^{\mathrm{b}}$, Timothy J. Wilding ${ }^{\mathrm{d}}$, Hiro Kusumoto ${ }^{\mathrm{a}}$, Chad R. Camp ${ }^{\mathrm{a}}$, Gil Shaulsky ${ }^{\mathrm{a}}$, Subhrajit Bhattacharya ${ }^{\mathrm{e}}$, Riley E. Perszyk ${ }^{\mathrm{a}}$, David S. Menaldino ${ }^{\mathrm{b}}$, Miranda J. McDaniel ${ }^{\mathrm{a}}$, Jing Zhang ${ }^{\mathrm{a}}$, Phuong Le ${ }^{\mathrm{a}}$, Tue G. Banke ${ }^{\mathrm{a}}$, Kasper B. Hansen ${ }^{\mathrm{a}, \mathrm{c}}$, James E. Huettner ${ }^{\mathrm{d}}$, Dennis C. Liotta $^{\mathrm{b}}$, Stephen F. Traynelis ${ }^{\mathrm{a}}$

\footnotetext{
a Emory University, Department of Pharmacology, 1510 Clifton Road, Atlanta, GA, 30322, USA

${ }^{\mathrm{b}}$ Emory University, Department of Chemistry, 1515 Dickey Drive, Atlanta, GA, 30322, USA

${ }^{c}$ University of Montana, Center for Biomolecular Structure and Dynamics, Center for Structural and Functional Neuroscience, Division for Biological Sciences, 32 Campus Drive, Missoula MT, 59812 USA

${ }^{\mathrm{d}}$ Washington University, Department of Cell Biology and Physiology, St Louis, MO, 63110, USA

${ }^{\mathrm{e}}$ Department of Drug Discovery and Development, Auburn University, Auburn, AL, 36849
}

\section{Supporting Information}

Table S1: Racemic EU1180-55 potentiation of NMDARs activated by $\mathrm{EC}_{30}$ concentration of agonist Table S2: Effect of racemic EU1180-55 on the glutamate deactivation time course

Table S3: Effect of EU1180-55 and EU1180-154 enantiomers on the glutamate deactivation time course

Table S4: Effect of EU1180-55 enantiomers on the response to brief $5 \mathrm{~ms}$ application of glutamate Table S5: Effect of (S)-EU1180-55 on the evoked NMDAR synaptic time course Table S6: EU1180-154 and EU1180-55 effects on GluK2-GluN1 /GluK2-GluN2 chimeric receptors Figure S1: EU1180-55 potentiation of NMDAR responses is diminished by residues encoded by GluN1 exon5 Figure S2: EU1180-55 effects on the response time course of NMDARs expressed in HEK293 cells Figure S3: EU1180-55 slows the NMDAR response rise time Figure S4: EU1180-55 enantiomers differentially alter the response time course to $5 \mathrm{~ms}$ application of glutamate Figure S5: Subunit-selective actions of EU1180-154 enantiomers

Figure S6: (S)-EU1180-154 does not alter the response of GluK2 receptors

Figure S7: Overlay of GYKI 53655 and EU1180-55 enantiomers

Figure S8: Comparison of sequence identity and similarity for the two pre-M1 pockets

Figure S9: The Ramachandran plots and associated statistics for models generated in this study

Figure S10: Molecular dynamics RMSD

Supplemental References 
Supplemental Table S1. Racemic EU1180-55 potentiation of NMDARs activated by $\mathrm{EC}_{30}$ concentration of agonist

\begin{tabular}{lcccc}
\hline & $\mathrm{EC}_{50}(\mu \mathrm{M})$ & Hill Slope & Maximal Response $(\%$ of control) & $\mathrm{N}$ \\
\hline GluN1/GluN2A & $7.4(6.6-8.2)$ & $2.6 \pm 0.23$ & $580 \pm 33$ & 8 \\
GluN1/GluN2B & $8.8(7.1-10)$ & $1.7 \pm 0.079$ & $370 \pm 38$ & 7 \\
GluN1/GluN2C & $4.3(3.7-4.8)$ & $1.1 \pm 0.068$ & $1200 \pm 54$ & 6 \\
GluN1/GluN2D & $4.6(4.3-4.9)$ & $1.4 \pm 0.043$ & $790 \pm 87$ & 8 \\
\hline
\end{tabular}

Racemic EU1180-55 effects on GluN1/GluN3 glycine-activated receptors

\begin{tabular}{ccc}
\hline & Current $(10 \mu$ M EU1180-55 $) /$ Current(vehicle $)$ & $\mathrm{N}$ \\
\hline GluN1 $^{\mathrm{FA}, \mathrm{TL} / \mathrm{GluN} 3 \mathrm{~A}}$ & $106 \pm 1.26 \%$ & 7 \\
GluN1/GluN3B $+0.5 \mu \mathrm{M}$ CGP-78608 & $95.3 \pm 1.75 \%$ & 7 \\
\hline
\end{tabular}

Mean fitted $\mathrm{EC}_{50}$ values are given with the $95 \%$ confidence interval, determined from the $\log \mathrm{EC}_{50}$ values. The mean Hill slope and maximal response from the fitted curve are given \pm SEM. $\mathrm{N}$ is the number of oocytes recorded.

GluN1(F484A, T518L)/GluN3A (GluN1 FA,TL/GluN3A) receptors were activated by $1 \mathrm{mM}$ glycine and GluN1/GluN3B receptors were activated by $1 \mathrm{mM}$ glycine in $0.5 \mu \mathrm{M}$ CGP-768608. The ratio of current was determined in the presence of drug to that in the absence of drug. The GluN1(FA,TL) mutations were used to reduce glycine binding to GluN1, which produces autoinhibition of the response. CGP-78608 selectively inhibits glycine binding to GluN1 (Grand et al., 2018; Zhu et al., 2020). 
Supplemental Table S2. Effect of racemic EU1180-55 on the glutamate deactivation time course

\begin{tabular}{|c|c|c|c|c|c|c|c|c|c|c|}
\hline \multirow[b]{2}{*}{$\begin{array}{c}1.5-2 \mathrm{sec} \\
\text { glutamate }\end{array}$} & \multicolumn{2}{|c|}{$-\operatorname{Amp}(\mathbf{p A})$} & \multicolumn{2}{|c|}{ Taufast (ms) } & \multicolumn{2}{|c|}{ Tauslow (ms) } & \multicolumn{2}{|c|}{ Tauw (ms) } & \multicolumn{2}{|c|}{$\%$ Fast } \\
\hline & Control & EU1180-55 & Control & EU1180-55 & Control & EU1180-55 & Control & EU1180-55 & Control & EU1180-55 \\
\hline GluN1/GluN2A & $937 \pm 208$ & $1526 \pm 278^{*}$ & $27 \pm 2.4$ & $98 \pm 11$ & $177 \pm 37$ & $913 \pm 283$ & $53 \pm 4.9$ & $184 \pm 32 *$ & $76 \pm 5.3$ & $83 \pm 4.0$ \\
\hline GluN1/GluN2B & $884 \pm 162$ & $1290 \pm 145^{*}$ & $196 \pm 36$ & $165 \pm 35$ & $737 \pm 63$ & $1020 \pm 126$ & $557 \pm 44$ & $786 \pm 118^{*}$ & $39 \pm 3.5$ & $31 \pm 4.8$ \\
\hline GluN1/GluN2C & $266 \pm 88$ & $767 \pm 270^{*}$ & $238 \pm 32$ & $510 \pm 89$ & $673 \pm 67$ & $1170 \pm 252$ & $451 \pm 29$ & $761 \pm 51 *$ & $49 \pm 5.9$ & $64 \pm 10$ \\
\hline GluN1/GluN2D & $135 \pm 23$ & $454 \pm 56^{*}$ & $1550 \pm 352$ & $1570 \pm 310$ & $6970 \pm 380$ & $8640 \pm 317$ & $4720 \pm 287$ & $7300 \pm 257 *$ & $41 \pm 4.9$ & $19 \pm 2.9$ \\
\hline \multirow[b]{2}{*}{$\begin{array}{c}5 \mathrm{~ms} \\
\text { glutamate }\end{array}$} & \multicolumn{2}{|c|}{$-\operatorname{Amp}(\mathbf{p A})$} & \multicolumn{2}{|c|}{ Taufast $(\mathrm{ms})$} & \multicolumn{2}{|c|}{ Tauslow $(\mathbf{m s})$} & \multicolumn{2}{|c|}{ Tauw $(\mathrm{ms})$} & \multicolumn{2}{|c|}{$\%$ Fast } \\
\hline & Control & EU1180-55 & Control & EU1180-55 & Control & EU1180-55 & Control & EU1180-55 & Control & EU1180-55 \\
\hline GluN1/GluN2A & $927 \pm 232$ & $990 \pm 254$ & $24 \pm 2.2$ & $84 \pm 14$ & $110 \pm 27$ & $414 \pm 140$ & $37 \pm 3.8$ & $154 \pm 33 *$ & $75 \pm 5.2$ & $64 \pm 7.3$ \\
\hline GluN1/GluN2B & $480 \pm 70$ & $1240 \pm 354 *$ & $203 \pm 22$ & $236 \pm 26$ & $849 \pm 74$ & $1570 \pm 226$ & $383 \pm 33$ & $506 \pm 56 *$ & $72 \pm 2.7$ & $80 \pm 2.1$ \\
\hline GluN1/GluN2C & $157 \pm 37$ & $733 \pm 191 *$ & $269 \pm 39$ & $454 \pm 92$ & $783 \pm 109$ & $1110 \pm 294$ & $429 \pm 27$ & $754 \pm 70 *$ & $62 \pm 9.7$ & $40 \pm 10$ \\
\hline GluN1/GluN2D & $71 \pm 9.5$ & $333 \pm 36 *$ & $991 \pm 277$ & $932 \pm 163$ & $6410 \pm 745$ & $7990 \pm 248$ & $4220 \pm 375$ & $6760 \pm 248 *$ & $39 \pm 4.7$ & $17 \pm 1.3$ \\
\hline
\end{tabular}

Agonist-evoked whole cell currents were recorded in response to rapid application of $100 \mu \mathrm{M}$ glutamate plus $30 \mu \mathrm{M}$ glycine for 1.5-2 sec (upper panel) or $5 \mathrm{~ms}$ (lower panel). 10 individual records were averaged for each cell and the deactivation time course following removal of glutamate fitted by a dual exponential function. The mean \pm SEM of fitted parameters from the indicated number of cells $(\mathrm{N})$ is given. $30 \mu \mathrm{M}$ glycine was present in all solutions. Racemic EU1180$55(30 \mu \mathrm{M})$ was added to the glycine-containing wash and the glutamate/glycine-containing solution and recordings repeated in the same cell. Recordings were made at $-70 \mathrm{mV}$. $* p<0.05$ by paired t-test of response amplitude (-Amp) and weighted tau $\left(\mathrm{Tau}_{\mathrm{W}}\right)$ using the Holm-Bonferroni correction to control for the family wise error rate; for all experiments, $\mathrm{n}=8-13$ cells. Power to detect an effect size of 1.5 for GluN2A-D was 0.96-0.99. 
Supplemental Table S3. Effect of EU1180-55 and EU1180-154 enantiomers on the glutamate deactivation time course

\begin{tabular}{|c|c|c|c|c|c|c|c|c|c|}
\hline & \multicolumn{2}{|c|}{-Amplitude (pA) } & \multicolumn{2}{|c|}{ TauFAST (ms) } & \multicolumn{2}{|c|}{ TausLow $(m s)$} & \multicolumn{2}{|c|}{ TauFAst $(\%)$} & \multirow[b]{2}{*}{$\mathbf{N}$} \\
\hline & Control & $\begin{array}{c}(S)- \\
\text { EU1180-55 } \\
\end{array}$ & Control & $\begin{array}{c}(S)- \\
\text { EU1180-55 } \\
\end{array}$ & Control & $\begin{array}{c}(S)- \\
\text { EU1180-55 } \\
\end{array}$ & Control & $\begin{array}{c}(S)- \\
\text { EU1180-55 } \\
\end{array}$ & \\
\hline GluN1/GluN2A & $4820 \pm 1110$ & $5962 \pm 1170$ & $57 \pm 6.2$ & $191 \pm 26$ & $309 \pm 24$ & $666 \pm 237$ & $90 \pm 2.1$ & $86 \pm 7.5$ & 9 \\
\hline GluN1/GluN2B & $1220 \pm 347$ & $1830 \pm 515^{*}$ & $286 \pm 31$ & $564 \pm 34$ & $937 \pm 124$ & $1700 \pm 135$ & $53 \pm 6.1$ & $64 \pm 4.7$ & 10 \\
\hline GluN1/GluN2C & $408 \pm 72$ & $689 \pm 122 *$ & $360 \pm 26$ & $450 \pm 36$ & $918 \pm 126$ & $1370 \pm 216$ & $69 \pm 4.8$ & $61 \pm 6.9$ & 16 \\
\hline GluN1/GluN2D & $346 \pm 57$ & $637 \pm 76^{*}$ & $2490 \pm 255$ & $2290 \pm 311$ & $8990 \pm 1700$ & $8060 \pm 476$ & $37 \pm 4.1$ & $28 \pm 3.2$ & 13 \\
\hline
\end{tabular}

\begin{tabular}{|c|c|c|c|c|c|c|c|c|c|}
\hline & \multicolumn{2}{|c|}{-Amplitude (pA) } & \multicolumn{2}{|c|}{ Taufast (ms) } & \multicolumn{2}{|c|}{ TausLow (ms) } & \multicolumn{2}{|c|}{ Taufast $(\%)$} & \multirow[b]{2}{*}{$\mathbf{N}$} \\
\hline & Control & $\begin{array}{c}(R)- \\
\text { EU1180-55 } \\
\end{array}$ & Control & $\begin{array}{c}(R)- \\
\text { EU1180-55 } \\
\end{array}$ & Control & $\begin{array}{c}(R)- \\
\text { EU1180-55 } \\
\end{array}$ & Control & $\begin{array}{c}(R)- \\
\text { EU1180-55 } \\
\end{array}$ & \\
\hline GluN1/GluN2A & $3890 \pm 923$ & $4200 \pm 974$ & $37 \pm 2.6$ & $57 \pm 4.7$ & $228 \pm 30$ & $240 \pm 18$ & $90 \pm 1.6$ & $82 \pm 2.1$ & 8 \\
\hline GluN1/GluN2B & $1280 \pm 243$ & $1380 \pm 221$ & $369 \pm 41$ & $464 \pm 56$ & $1130 \pm 116$ & $1380 \pm 192$ & $62 \pm 5.6$ & $56 \pm 5.3$ & 15 \\
\hline GluN1/GluN2C & $539 \pm 174$ & $702 \pm 184$ & $351 \pm 39$ & $413+44$ & $987 \pm 110$ & $1180 \pm 85$ & $59 \pm 8.2$ & $45 \pm 8.1$ & 10 \\
\hline GluN1/GluN2D & $373 \pm 56$ & $392 \pm 82$ & $2720 \pm 343$ & $3220 \pm 592$ & $8850 \pm 570$ & $9610 \pm 352$ & $32 \pm 4.6$ & $26 \pm 3.8$ & 13 \\
\hline
\end{tabular}

\begin{tabular}{|c|c|c|c|c|c|c|c|c|c|}
\hline & \multicolumn{2}{|c|}{-Amplitude (pA) } & \multicolumn{2}{|c|}{ Taufast (ms) } & \multicolumn{2}{|c|}{ Tauslow (ms) } & \multicolumn{2}{|c|}{ Taufast (\%) } & \multirow[b]{2}{*}{$\mathbf{N}$} \\
\hline & Control & $\begin{array}{c}(S)- \\
\text { EU1180-154 } \\
\end{array}$ & Control & $\begin{array}{c}(S)- \\
\text { EU1180-154 } \\
\end{array}$ & Control & $\begin{array}{c}(S)- \\
\text { EU1180-154 } \\
\end{array}$ & Control & $\begin{array}{c}(S)- \\
\text { EU1180-154 } \\
\end{array}$ & \\
\hline GluN1/GluN2A & $6290 \pm 853$ & $6120 \pm 953$ & $51 \pm 4.0$ & $120 \pm 25$ & $415 \pm 54$ & $467 \pm 85$ & $92 \pm 1.3$ & $91 \pm 2.5$ & 8 \\
\hline GluN1/GluN2B & $508+161$ & $758 \pm 198^{*}$ & $331 \pm 32$ & $609 \pm 38$ & $1070 \pm 88$ & $1980 \pm 196$ & $52 \pm 5.6$ & $69 \pm 4.5$ & 10 \\
\hline GluN1/GluN2C & $235 \pm 73$ & $390 \pm 93 *$ & $239 \pm 33$ & $396 \pm 22$ & $644 \pm 45$ & $1032+119$ & $53 \pm 9.9$ & $66 \pm 5.1$ & 6 \\
\hline \multirow[t]{3}{*}{ GluN1/GluN2D } & $172 \pm 19$ & $361 \pm 75^{*}$ & $1830 \pm 182$ & $3160 \pm 839$ & $7140 \pm 264$ & $7520 \pm 1180$ & $30 \pm 3.4$ & $39 \pm 9.2$ & 9 \\
\hline & \multicolumn{2}{|c|}{-Amplitude (pA) } & \multicolumn{2}{|c|}{ Taufast (ms) } & \multicolumn{2}{|c|}{ TausLow (ms) } & \multicolumn{2}{|c|}{ Taufast $(\%)$} & \\
\hline & Control & $\begin{array}{c}(R)- \\
\text { EU1180-154 } \\
\end{array}$ & Control & $\begin{array}{c}(R)- \\
\text { EU1180-154 } \\
\end{array}$ & Control & $\begin{array}{c}(R)- \\
\text { EU1180-154 } \\
\end{array}$ & Control & $\begin{array}{c}(R)- \\
\text { EU1180-154 } \\
\end{array}$ & $\mathbf{N}$ \\
\hline GluN1/GluN2A & $2620 \pm 520$ & $2200 \pm 447$ & $36 \pm 3.5$ & $47 \pm 3.9$ & $242 \pm 18$ & $342 \pm 40$ & $89 \pm 1.9$ & $92 \pm 2.0$ & 15 \\
\hline GluN1/GluN2B & $762 \pm 203$ & $757 \pm 184$ & $315 \pm 33$ & $363 \pm 28$ & $995 \pm 91$ & $1139 \pm 71$ & $51 \pm 5.1$ & $54 \pm 4.5$ & 12 \\
\hline GluN1/GluN2C & $243 \pm 61$ & $312 \pm 91$ & $327 \pm 24$ & $394 \pm 17$ & $998+195$ & $1876 \pm 368$ & $82 \pm 5.5$ & $88 \pm 3.5$ & 8 \\
\hline GluN1/GluN2D & $178 \pm 38$ & $163+57$ & $2010 \pm 327$ & $1870 \pm 168$ & $8330 \pm 940$ & $7810 \pm 291$ & $34+5.2$ & $24 \pm 2.0$ & 7 \\
\hline
\end{tabular}

Agonist-evoked whole cell currents were recorded in response to rapid application of $100 \mu \mathrm{M}$ glutamate plus $30 \mu \mathrm{M}$ glycine for $1.5 \mathrm{sec} .10$ individual records were averaged for each cell and the deactivation time course following removal of glutamate fitted by a dual exponential function. The mean \pm SEM of fitted parameters from the indicated number of cells $(\mathrm{N})$ is given. $30 \mu \mathrm{M}$ glycine was present in all solutions, and $(S)$ - or $(R)$-EU1180-55 $(15 \mu \mathrm{M})$ and $(S)$ - or $(R)$-EU1180$154(5 \mu \mathrm{M})$ were added to the glycine-containing wash and the glutamate/glycine-containing solution, with recordings repeated in the same cell. Recordings were made at $-70 \mathrm{mV}$. For some experiments (e.g. $(R)$-EU1180-55 and $(R)$-EU1180154), the current response amplitude gradually diminished over the acquisition of independent sweeps and wash-in of drug, preventing an accurate determination of the drug effect on response amplitude. This prompted us to evaluate the effect of test compound on amplitude using a direct transition into drug-containing solutions during glutamate application using a rapid double-barreled fluid exchange system (see Table 2). * $p<0.05$ paired t-test of only response amplitude. Power to detect an effect size of 1.5 for GluN2A-D was 0.83-0.99. 
Supplemental Table S4. Effect of EU1180-55 enantiomers on the response to brief $5 \mathrm{~ms}$ application of glutamate

\begin{tabular}{|c|c|c|c|c|c|c|c|c|c|c|}
\hline \multirow[b]{2}{*}{5 ms glutamate } & \multicolumn{2}{|c|}{$\begin{array}{c}\text {-Amplitude } \\
\text { (pA) }\end{array}$} & \multicolumn{2}{|c|}{$\begin{array}{l}\text { Deactivation } \\
\text { Taufast (ms) }\end{array}$} & \multicolumn{2}{|c|}{$\begin{array}{l}\text { Deactivation } \\
\text { TausLow (ms) }\end{array}$} & \multicolumn{2}{|c|}{$\begin{array}{c}\text { Deactivation } \\
\text { Tauw (ms) }\end{array}$} & \multicolumn{2}{|c|}{$\begin{array}{c}\text { Taufast } \\
(\%)\end{array}$} \\
\hline & Control & $\begin{array}{c}(S)- \\
\text { EU1180-55 } \\
\end{array}$ & Control & $\begin{array}{c}(S)- \\
\text { EU1180-55 } \\
\end{array}$ & Control & $\begin{array}{c}(S)- \\
\text { EU1180-55 } \\
\end{array}$ & Control & $\begin{array}{c}(S)- \\
\text { EU1180-55 } \\
\end{array}$ & Control & $\begin{array}{c}(S)- \\
\text { EU1180-55 }\end{array}$ \\
\hline GluN1/GluN2A & $1830 \pm 575$ & $2010 \pm 527$ & $42 \pm 8.5$ & $188 \pm 30$ & $149 \pm 36$ & $588 \pm 187$ & $58 \pm 8.6$ & $303 \pm 177$ & $80 \pm 7.7$ & $78 \pm 9.3$ \\
\hline GluN1/GluN2B & $1010 \pm 278$ & $1760 \pm 407 *$ & $227 \pm 35$ & $350 \pm 65$ & $859 \pm 111$ & $1350 \pm 126$ & $479 \pm 26$ & $729 \pm 85$ & $54 \pm 7.6$ & $59 \pm 6.4 *$ \\
\hline GluN1/GluN2C & $426 \pm 127$ & $616 \pm 142 *$ & $270 \pm 23$ & $310 \pm 50$ & $722 \pm 103$ & $811 \pm 87$ & $469 \pm 27$ & $646 \pm 30$ & $50 \pm 7.8$ & $39 \pm 7.5$ \\
\hline GluN1/GluN2D & $206 \pm 39$ & $392 \pm 65 *$ & $1010 \pm 149$ & $1510 \pm 332$ & $5950 \pm 361$ & $7920 \pm 821$ & $4830 \pm 331$ & $5700 \pm 525$ & $23 \pm 2.7$ & $33 \pm 3.2 *$ \\
\hline \multirow[b]{2}{*}{5 ms glutamate } & \multicolumn{2}{|c|}{$\begin{array}{c}\text {-Amplitude } \\
\text { (pA) }\end{array}$} & \multicolumn{2}{|c|}{$\begin{array}{l}\text { Deactivation } \\
\text { Taufast (ms) }\end{array}$} & \multicolumn{2}{|c|}{$\begin{array}{c}\text { Deactivation } \\
\text { TausLow (ms) }\end{array}$} & \multicolumn{2}{|c|}{$\begin{array}{c}\text { Deactivation } \\
\text { Tauw (ms) }\end{array}$} & \multicolumn{2}{|c|}{$\begin{array}{c}\text { Taufast } \\
(\%)\end{array}$} \\
\hline & Control & $\begin{array}{c}(R)- \\
\text { EU1180-55 } \\
\end{array}$ & Control & $\begin{array}{c}(R)- \\
\text { EU1180-55 } \\
\end{array}$ & Control & $\begin{array}{c}(R)- \\
\text { EU1180-55 } \\
\end{array}$ & Control & $\begin{array}{c}(R)- \\
\text { EU1180-55 } \\
\end{array}$ & Control & $\begin{array}{c}(R)- \\
\text { EU1180-55 } \\
\end{array}$ \\
\hline GluN1/GluN2A & $1860 \pm 718$ & $2270 \pm 778$ & $45 \pm 5.1$ & $58 \pm 5.8$ & $195 \pm 17$ & $309 \pm 96$ & $57 \pm 8.8$ & $89 \pm 8.1$ & $89 \pm 4.4$ & $72 \pm 9.9$ \\
\hline GluN1/GluN2C & $393 \pm 132$ & $530 \pm 139$ & $297 \pm 56$ & $333 \pm 58$ & $779 \pm 114$ & $1180 \pm 215$ & $530 \pm 26$ & $801 \pm 57$ & $43 \pm 7.9$ & $33 \pm 9.1$ \\
\hline GluN1/GluN2D & $204 \pm 45$ & $238 \pm 67$ & $1320 \pm 210$ & $1420 \pm 260$ & $7277 \pm 389$ & $8770 \pm 607$ & $5970 \pm 266$ & $7380 \pm 459$ & $22 \pm 3.2$ & $18 \pm 1.7$ \\
\hline
\end{tabular}

Agonist-evoked whole cell currents were recorded in response to rapid application of $100 \mu \mathrm{M}$ glutamate plus $30 \mu \mathrm{M}$ glycine for $5 \mathrm{~ms}$. 10 individual records were averaged for each cell and the deactivation time course following removal of glutamate fitted by a dual exponential function. Mean \pm SEM are presented. $30 \mu \mathrm{M}$ glycine was present in all solutions, and $(S)$ - or $(R)$-EU1180-55 $(15 \mu \mathrm{M})$ were added to the glycine-containing wash and the glutamate/glycine-containing solution, with recordings repeated in the same cell. Recordings were made at $-70 \mathrm{mV} ; \mathrm{N}=10-17$ cells for all. For some experiments (e.g. $(R)$-EU1180-55), the current response amplitude gradually diminished over the acquisition of independent sweeps and wash in of drug, preventing an accurate determination of the drug effect on response amplitude. $* p<0.05$ paired t-test of only response amplitude. Power to detect an effect size of 1.5 for GluN2A-D was 0.98-0.99. 
Supplemental Table S5: Effect of $(S)$-EU1180-55 on the evoked NMDA receptor synaptic time course

\begin{tabular}{|c|c|c|c|c|c|c|}
\hline & \multicolumn{3}{|c|}{$20 \boldsymbol{\mu M}(S)-\mathbf{E U 1 1 8 0 - 5 5}$} & \multicolumn{3}{|c|}{ DMSO } \\
\hline & Control & Drug & $\begin{array}{c}\text { Fold } \\
\text { Change }\end{array}$ & Control & Vehicle & $\begin{array}{c}\text { Fold } \\
\text { Change }\end{array}$ \\
\hline Rise Time (ms) & $6.6 \pm 1.2$ & $7.7 \pm 0.9$ & 1.28 & $10.3 \pm 1.2$ & $9.7 \pm 1.2$ & 0.96 \\
\hline Peak Amplitude (-pA) & $134 \pm 17$ & $165 \pm 55$ & $1.21 *$ & $123 \pm 16$ & $126 \pm 16$ & $1.05 n s$ \\
\hline Taufast (ms) & $30 \pm 7.4$ & $25 \pm 14$ & 0.92 & $38 \pm 5.8$ & $38 \pm 6.7$ & 0.99 \\
\hline Tauslow (ms) & $103 \pm 9.4$ & $130 \pm 25$ & 1.29 & $76 \pm 7.1$ & $85 \pm 9.0$ & 1.13 \\
\hline$\%$ Taufast & $62 \pm 4.7$ & $50 \pm 7.0$ & 0.82 & $78 \pm 2.4$ & $74 \pm 2.2$ & 0.95 \\
\hline Tauw (ms) & $132 \pm 12$ & $155 \pm 38$ & $1.19 *$ & $114 \pm 11$ & $123 \pm 13$ & $1.08 n s$ \\
\hline Charge Transfer $(\mathbf{p A} / \mathbf{s})$ & $18.0 \pm 0.4$ & $26.0 \pm 0.8$ & 1.46 & $14.4 \pm 0.3$ & $15.9 \pm 0.3$ & 1.12 \\
\hline
\end{tabular}

NMDAR-mediated EPSCs were recorded in the presence of $10 \mu \mathrm{M}$ NBQX, $10 \mu \mathrm{M}$ gabazine, and $0.2 \mathrm{mM} \mathrm{Mg}^{2+}$. Rise time was measured as the time the EPSC took to rise from 10-90\% of the amplitude. Tau $\mathrm{W}_{\mathrm{W}}$ is the weighted average of the fast and slow time constants (see Methods). Fold change is the ratio of the measured parameter in the presence of $(S)$-EU118055 or DMSO to that in the absence of drug or DMSO. Charge transfer was calculated from the integral under the evoked EPSC. $\mathrm{N}=8$ cells for each condition; recordings were made over a minimum of four mice per condition. * $\mathrm{p}<0.025$ (corrected for family wise error); $n s \mathrm{p}>0.1$. Other parameters were not tested for statistical significance. Power to detect an effect size of 0.5 was 0.97 . 
Supplemental Table S6: EU1180-154 and EU1180-55 effects on GluK2-GluN1/GluK2-GluN2 chimeric receptors

\begin{tabular}{|c|c|c|c|c|}
\hline & $\begin{array}{c}\text { Current ratio } \\
(S) \text {-EU1180-154 / } \\
\text { Control }\end{array}$ & $\begin{array}{l}\text { Standard } \\
\text { Deviation }\end{array}$ & SEM & $\mathbf{N}$ \\
\hline GluN1 / GluN2B & 1.50 & 0.44 & 0.083 & 28 \\
\hline GluN1(ABD,TMD)-GluK2(NTD) / GluN2B(ABD,TMD)-GluK2(NTD) & $2.04 *$ & 0.73 & 0.21 & 12 \\
\hline GluN1(TMD)-GluK2(NTD,ABD) / GluN2B(TMD)-GluK2(NTD,ABD) & 1.54 & 0.39 & 0.077 & 25 \\
\hline GluN1(NTD,ABD)-GluK2(TMD) / GluN2B(NTD,ABD)-GluK2(TMD) & $1.00 *$ & 0.17 & 0.038 & 21 \\
\hline GluK2(Q) & 0.98 & 0.072 & 0.032 & 5 \\
\hline \multirow[t]{2}{*}{ GluK2(R) } & 1.04 & 0.059 & 0.024 & 6 \\
\hline & $\begin{array}{l}\text { Current ratio } \\
(R, S) \text {-EU1180-55 } \\
\text { / Control }\end{array}$ & $\begin{array}{l}\text { Standard } \\
\text { Deviation }\end{array}$ & SEM & $\mathbf{N}$ \\
\hline GluN1 / GluN2B & 1.57 & 0.40 & 0.18 & 5 \\
\hline GluN1(ABD/TMD)-GluK2(NTD) / GluN2B(ABD/TMD)-GluK2(NTD) & 1.41 & 0.16 & 0.061 & 7 \\
\hline GluN1(NTD,ABD)-GluK2(TMD) / GluN2B(NTD,ABD)-GluK2(TMD) & $0.94 *$ & 0.079 & 0.028 & 8 \\
\hline GluN1 / GluN2A & 1.50 & 0.45 & 0.18 & 6 \\
\hline GluN1(ABD,TMD)-GluK2(NTD) / GluN2A(ABD,TMD)-GluK2(NTD) & 1.40 & 0.32 & 0.16 & 4 \\
\hline GluN1(TMD)-GluK2(NTD,ABD) / GluN2A(TMD)-GluK2(NTD,ABD) & 1.32 & 0.16 & 0.94 & 3 \\
\hline GluK2(Q) $)^{\#}$ & 0.96 & 0.27 & 0.09 & 9 \\
\hline
\end{tabular}

The chimeric GluN1 and GluN2 subunits contained the domain(s) indicated from NMDA and the domain(s) indicated from kainate receptor GluK2(Q). Both GluN1 and GluN2 possessed the indicated domains. In the upper table, agonistevoked currents were recorded in response to brief application of $10 \mu \mathrm{M}$ NMDA plus $10 \mu \mathrm{M}$ glycine for approximately $20 \mathrm{sec}$ to wild type and chimeric receptors with the NMDAR ABD. Wild type GluK2(Q) and (R), as well as the chimeric receptors with the GluK2 ABD were activated by application of $10 \mu \mathrm{M}$ kainate. $(S)$-EU1180-154 (3 $\mu \mathrm{M}$, vehicle $0.033 \%$ DMSO) was added to the control and agonist-containing solutions. The lower table shows the effects of $30 \mu \mathrm{M}$ racemic EU1180-55 or vehicle (5 mM $\beta$-hydroxy-propylcyclodextrin, 0.15\% DMSO) co-applied with $100 \mu \mathrm{M}$ glutamate and 30 $\mu \mathrm{M}$ glycine to HEK cells transfected with the indicated subunit combinations. All recordings were made from transiently transfected HEK-293 cells held at $-80 \mathrm{mV}$. $\mathrm{N}$ is the number of cells.

* denotes significant difference of chimeric NMDARs from wild type NMDARs (one-way ANOVA, with post hoc Bonferroni comparison to control for multiple comparisons). For $(S)$-EU1180-154, power to detect an effect size of 0.5 was 0.97; for EU1180-55 on GluN2B chimeras, power to detect an effect size of 0.8 was 0.97. Homomeric GluK2 kainate receptors were unaffected by $(S)$-EU1180-154 and racemic EU1180-55.

\# Data for the GluK2(Q) response to $30 \mu \mathrm{M}$ EU1180-55 was reproduced from Strong et al. (2017). 

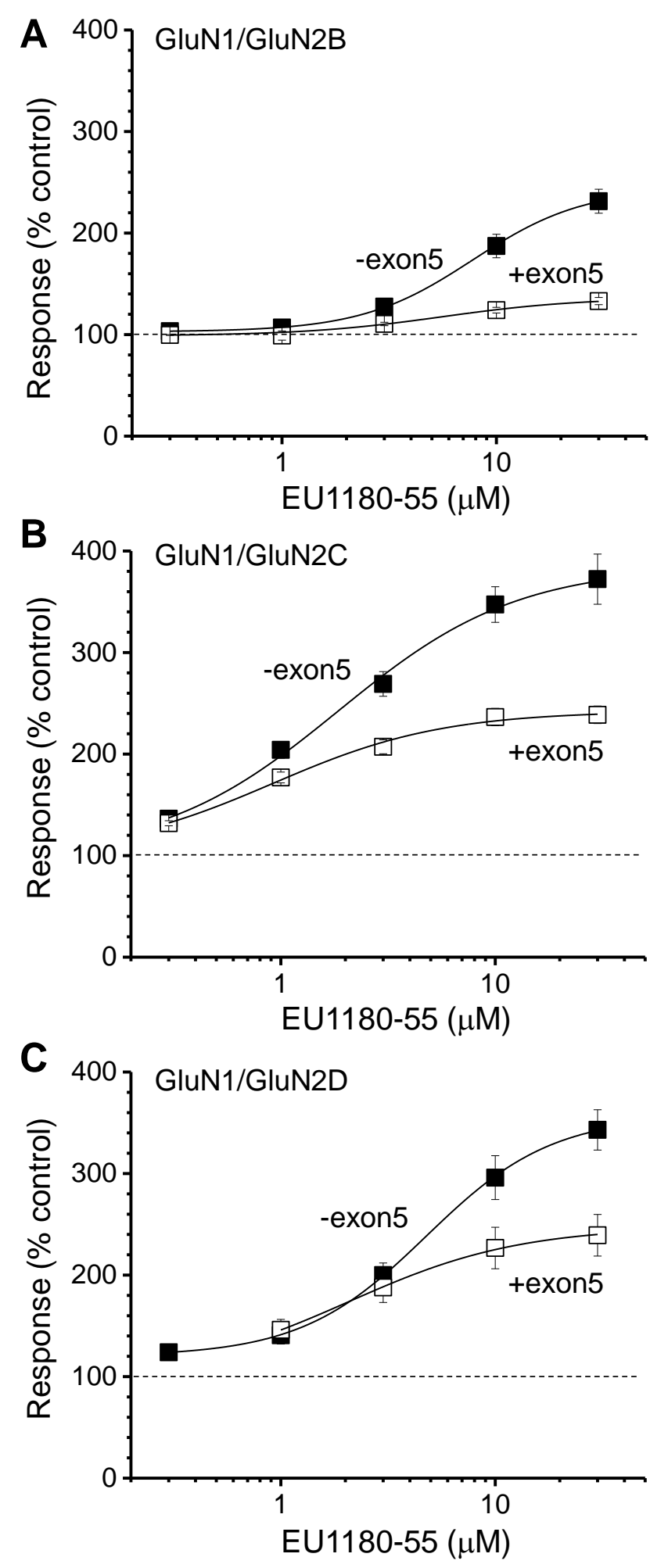

Supplemental Figure S1. EU1180-55 potentiation of NMDAR responses is diminished by residues encoded by GluN1 exon5. A) Concentration-response curve for EU1180-55 enhancement of GluN1/GluN2B receptors with and without alternatively spliced GluN1 exon5 recorded from Xenopus laevis oocytes in response to maximally effective concentrations of glutamate and glycine. $\mathrm{EC}_{50}$ values and maximal potentiation were $8 \mu \mathrm{M}$ and $244 \%$ of control (-exon5, $\mathrm{n}=13$ ) and $6 \mu \mathrm{M}$ and $136 \%$ of control (+exon5, $\mathrm{n}=18$ ). B) Similar analyses of responses of GluN1 with and without exon5 co-expressed with GluN2C. $\mathrm{EC}_{50}$ values and maximal potentiation of GluN1/GluN2C were $1.9 \mu \mathrm{M}$ and $385 \%$ of control (-exon5, n=8) and $0.5 \mu \mathrm{M}$ and $249 \%$ of control (+exon5, n=7). C) $\mathrm{EC}_{50}$ values and maximal potentiation of GluN1/GluN2D were $5 \mu \mathrm{M}$ and $357 \%$ of control (-exon5, $\mathrm{n}=16$ ) and $2 \mu \mathrm{M}$ and $248 \%$ of control (+exon5, $\mathrm{n}=15$ ). 

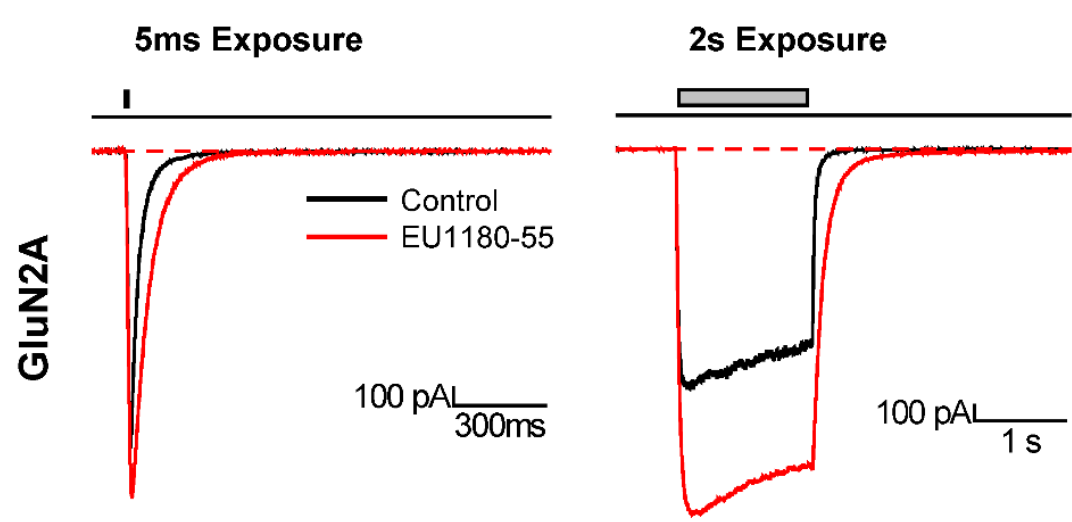
2s Exposure
Normalized Deactivation
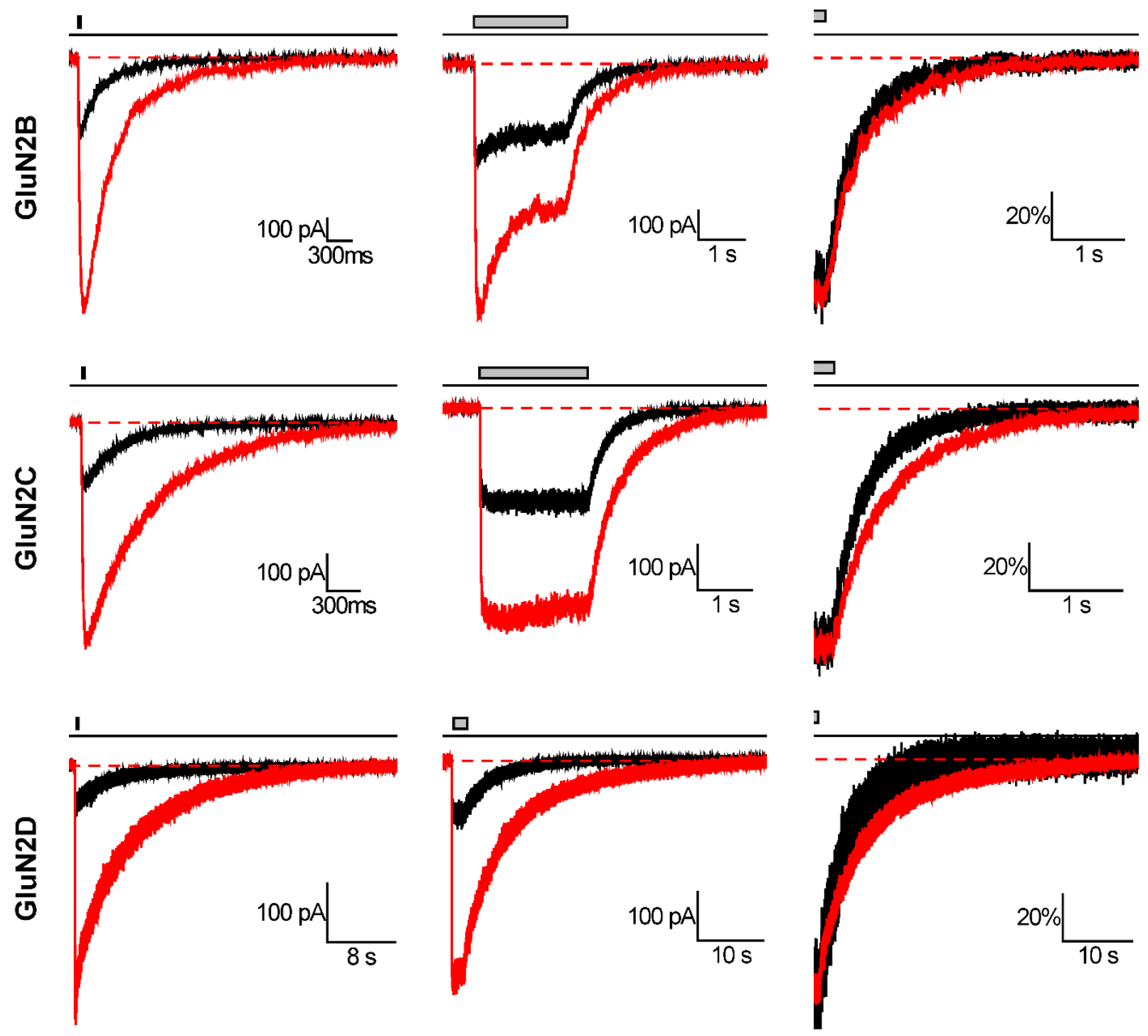

Supplemental Figure S2. EU1180-55 effects on the response time course of NMDARs expressed in HEK293 cells. Left panel: Representative current response to brief $5 \mathrm{~ms}$ glutamate application $(100 \mu \mathrm{M})$ with and without EU1180-55 $(30 \mu \mathrm{M})$ on all GluN1/GluN2 NMDAR combinations. The grey box represents when cell was exposed to the glutamatecontaining solutions and the receptors were activated. Middle panel: Representative current response to a prolonged glutamate application with and without EU1180-55. Right Panel: The current responses were normalized to steady state response to illustrate the differences in the deactivation time course. For all panels, glycine $(30 \mu \mathrm{M})$ and EU1180-55 (when added) were present in all solutions, symbolized by the continuous black line. Currents were recorded at $-60 \mathrm{mV}$. 


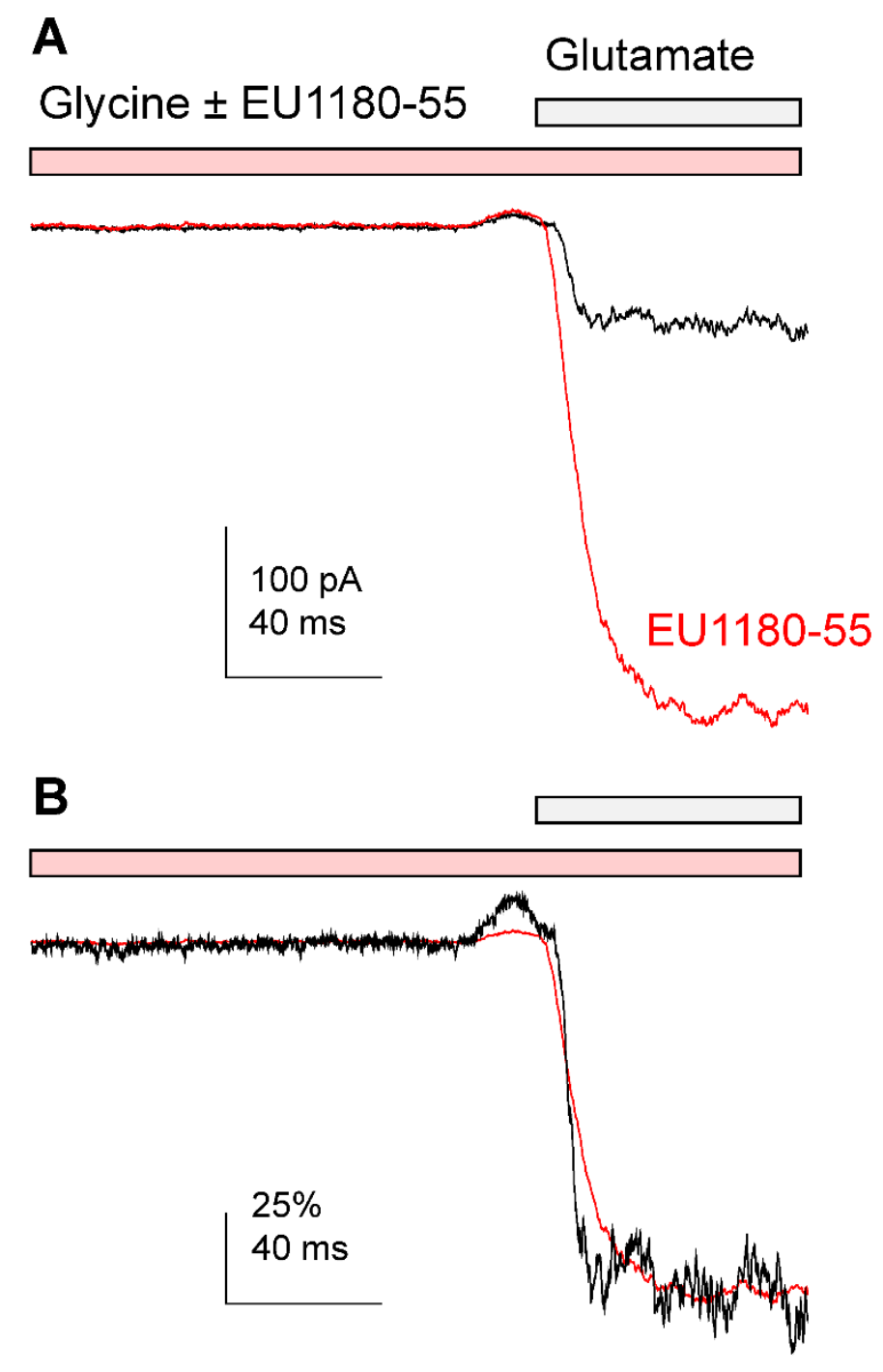

Supplemental Figure S3. EU1180-55 slows the NMDAR response rise time. A) Current response from an HEK cell expressing GluN1/GluN2D to rapid application of $1 \mathrm{mM}$ glutamate (gray bar, $\mathrm{V}_{\mathrm{HOLD}}-60 \mathrm{mV}$ ). $30 \mu \mathrm{M}$ glycine was present in all solutions, supplemented with either vehicle (0.15\% DMSO, $5 \mathrm{mM} \beta$-hydroxypropylcyclodextrin) or 30 $\mu \mathrm{M}$ racemic EU1180-55 in vehicle (red bar). Responses shown are the average of 7 (control) or 20 responses (EU118055) current waveforms. B) The responses in (A) are shown normalized and aligned on the point of steepest rise to illustrate the slowing of the rise time by EU1180-55. 
A 1 GluN1/GluN2A

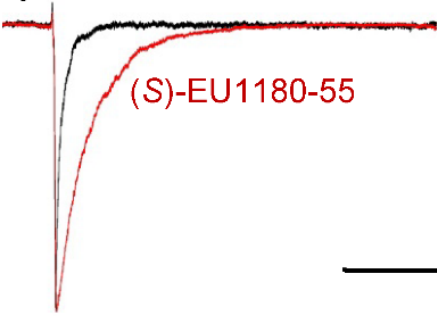

$B_{1}$ GluN1/GluN2B

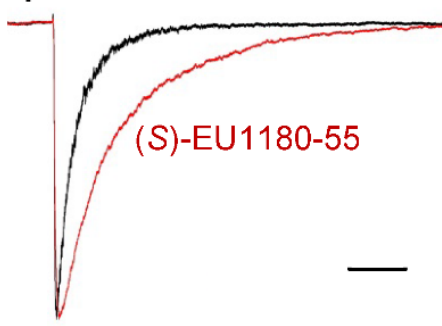

$C_{1}$ GluN1/GluN2C
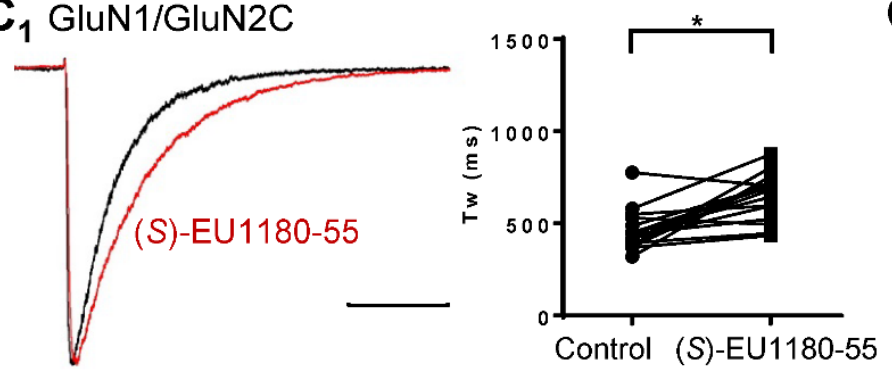

C $_{2}$ GluN1/GluN2C

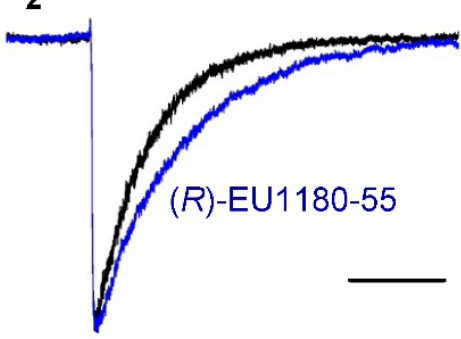

$B_{2}$ GluN1/GluN2B
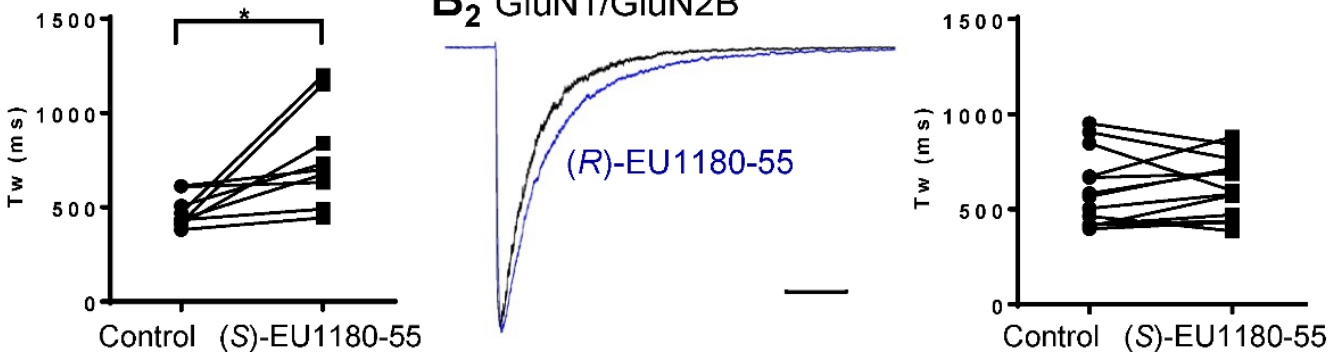

$D_{1}$ GluN1/GluN2D
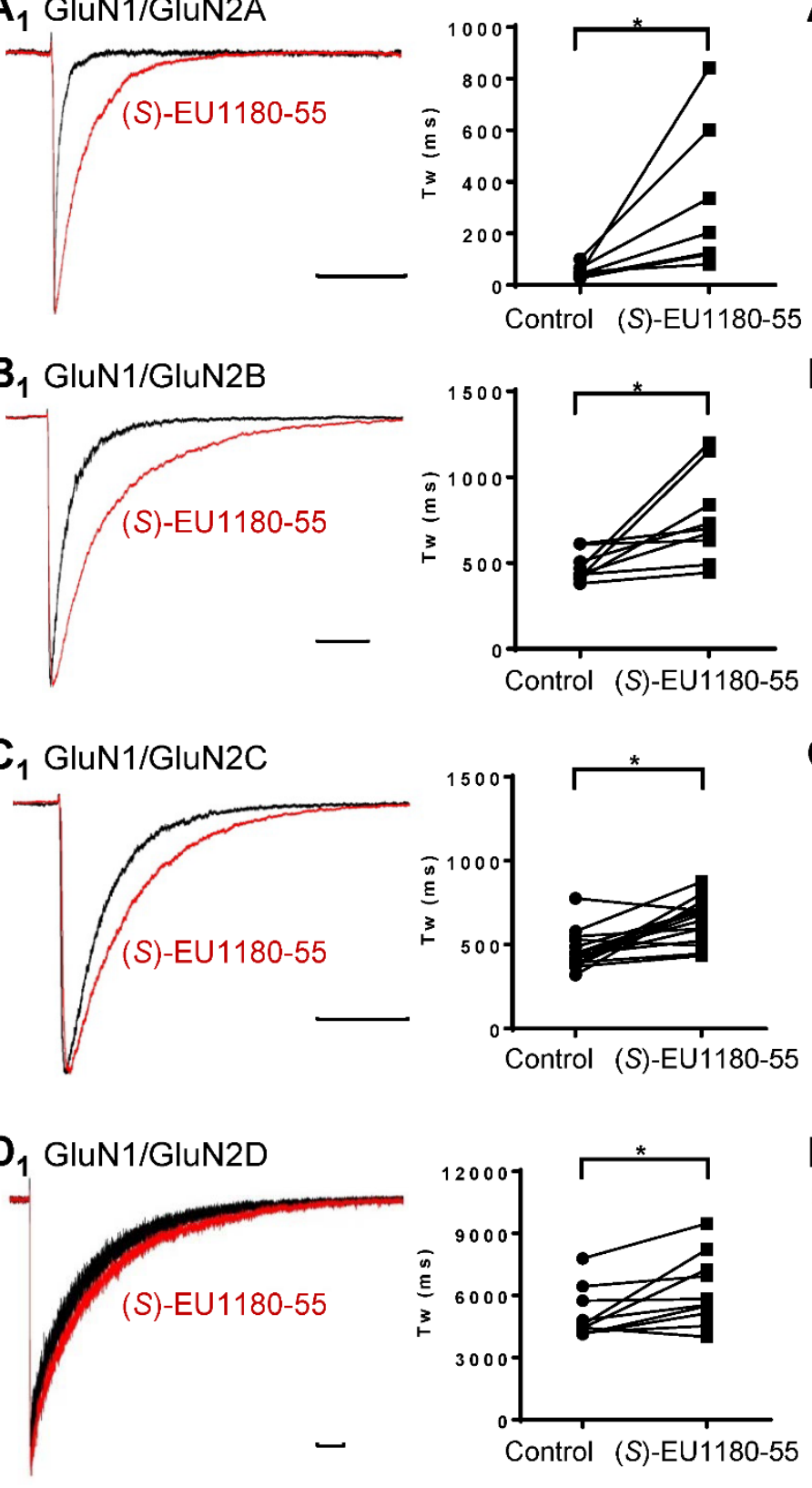

$A_{2}$ GluN1/GluN2A

$(R)$-EU1180-55

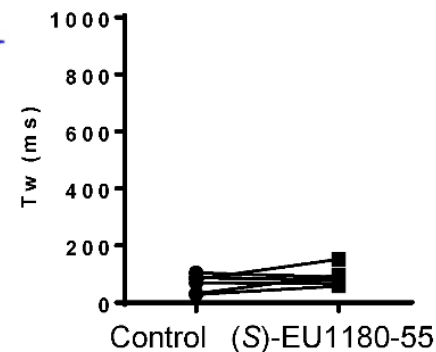

Control (S)-EU1180-55

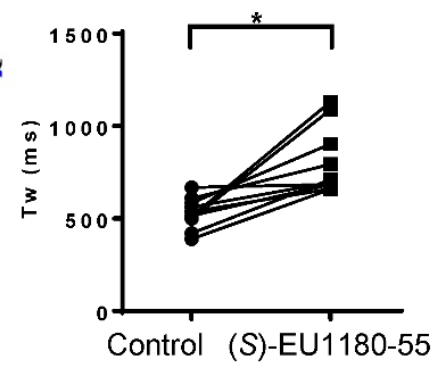

$D_{2}$ GluN1/GluN2D

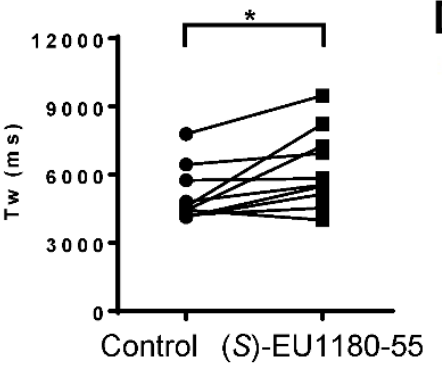

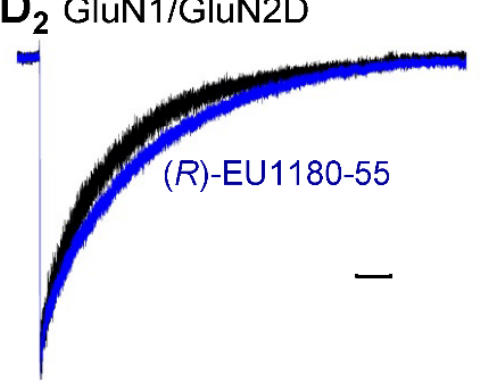

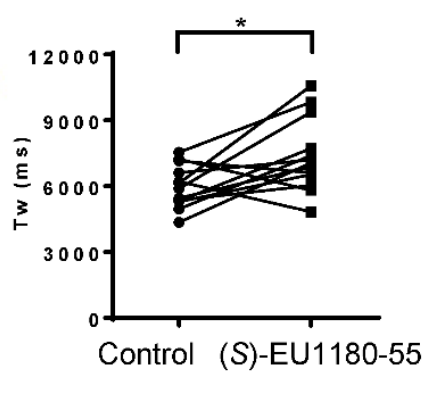

Supplemental Figure S4. EU1180-55 enantiomers differentially alter the response time course to 5 ms application of glutamate. $\left.A_{1}\right)$ Representative GluN1/GluN2A currents recorded from HEK cells in response to brief 5 ms glutamate application $(100 \mu \mathrm{M})$ with and without $(S)$-EU1180-55 $(15 \mu \mathrm{M})$ were normalized and superimposed. $\left(\mathrm{A}_{2}\right)$

Representative GluN1/GluN2A current response to brief glutamate application $(100 \mu \mathrm{M})$ with and without $(R)$-EU1180$\mathbf{5 5}(15 \mu \mathrm{M})$ were normalized and superimposed. The panels on the right summarize the weighted tau values before (circles) and during drug treatment (squares). The calibration bar is $1 \mathrm{sec}$. Similar recordings are shown for GluN1/GluN2B $\left(B_{1,2}\right)$, GluN1/GluN2C $\left(C_{1,2}\right)$, and GluN1/GluN2D $\left(D_{1,2}\right)$. For all panels, glycine $(30 \mu M)$ and EU118055 (when added) were present in all solutions. Currents were recorded at $-60 \mathrm{mV}$. * indicates $\mathrm{p}<0.05$ (paired t-test). 
$A_{1}$

S)-EU1180-154

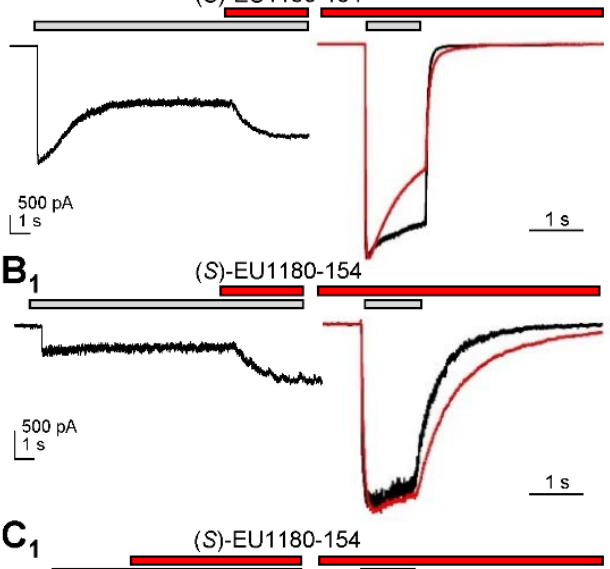

$\mathrm{C}_{1}$

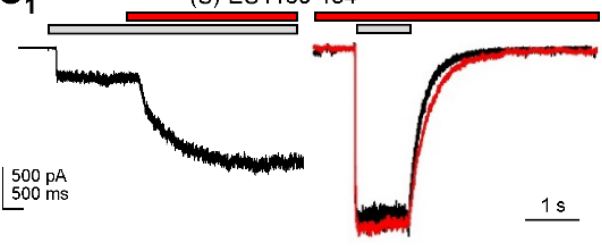

$\mathrm{D}_{1}$

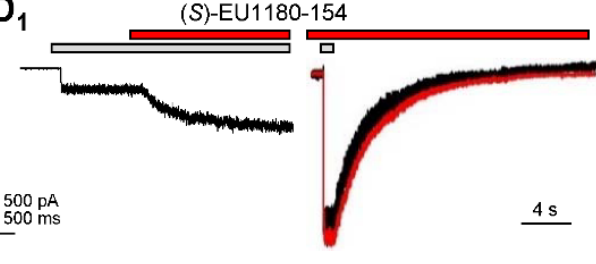

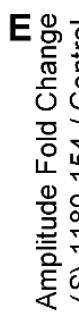

(S)-EU1180-154

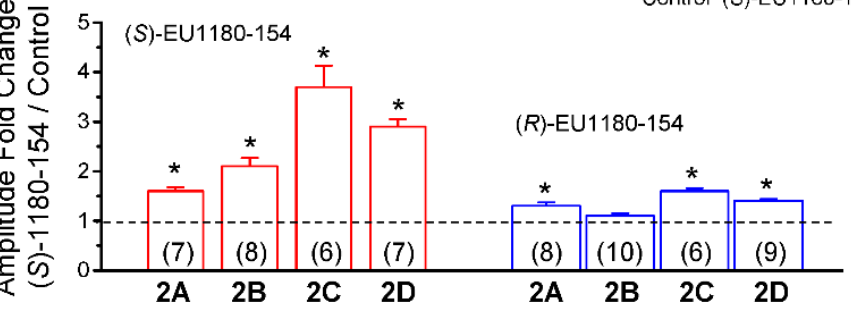

$\mathrm{A}_{2}$

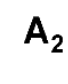

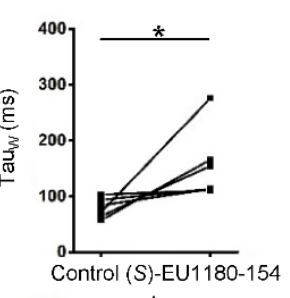
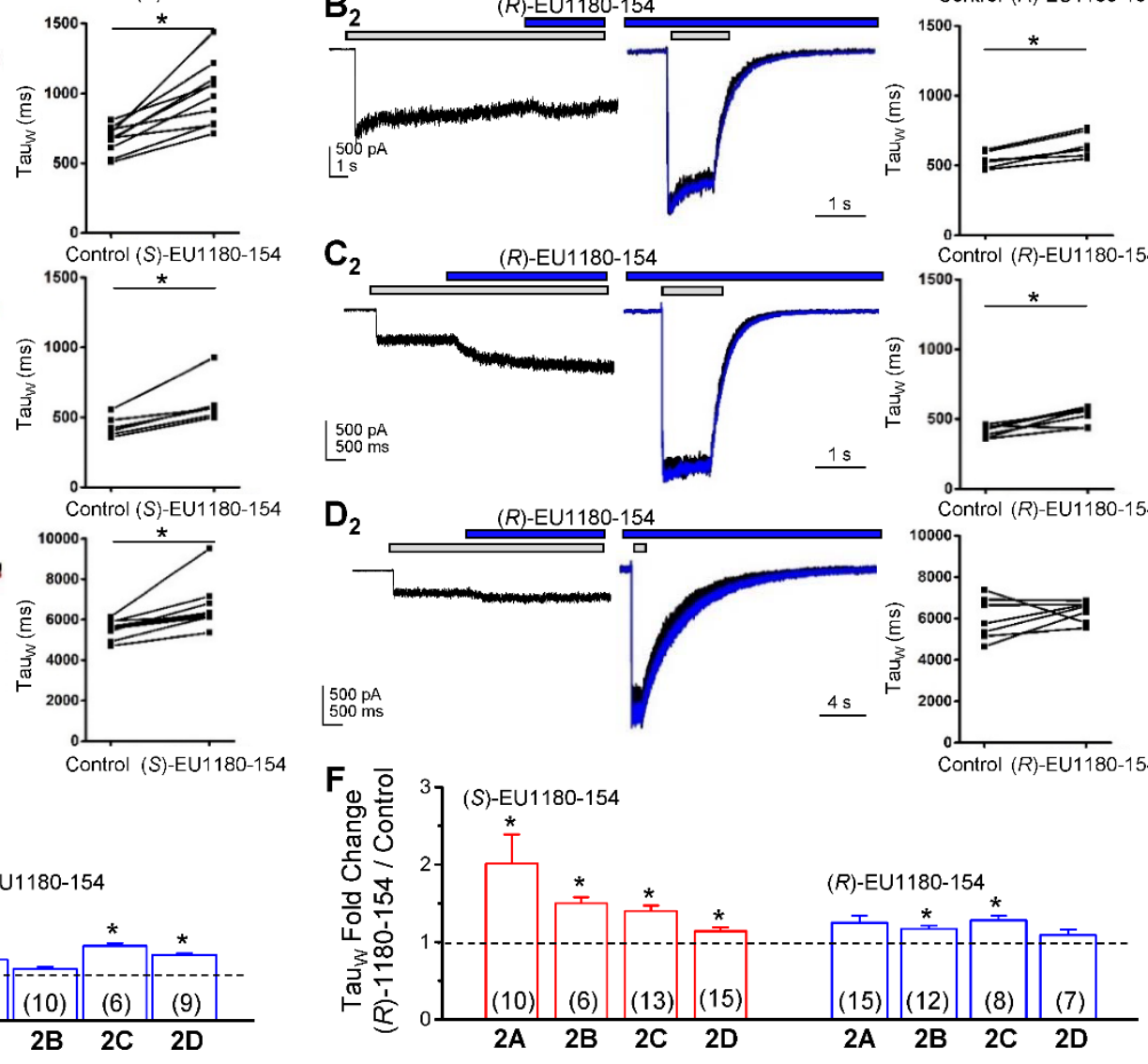

Supplemental Figure S5. Subunit-selective actions of EU1180-154 enantiomers. $\left.A_{1,2}\right)$ Left panel A representative whole cell current response from an HEK cell expressing GluN1/GluN2A to $100 \mu \mathrm{M}$ glutamate and $30 \mu \mathrm{M}$ glycine (plus vehicle, $0.05 \%$ DMSO), followed by a switch to glutamate/glycine plus $5 \mu \mathrm{M}(S)$-EU1180-154 $\left(\mathrm{A}_{1}\right)$ or $5 \mu \mathrm{M}(R)$ - EU1180$154\left(\mathrm{~A}_{2}\right)$. Middle panel Normalized mean whole cell current time course recorded in response to 1.5 second rapid application of $100 \mu \mathrm{M}$ glutamate and $30 \mu \mathrm{M}$ glycine is shown in the absence (black) and presence of $5 \mu \mathrm{M}(S)$ - EU1180154 (red) or $5 \mu \mathrm{M}(R)$-EU1180-154 (blue) enantiomers; EU1180-154 and glycine were in the wash solution prior to application of glutamate. Right panel Plot of change in weighted deactivation tau in vehicle or test compound. The same experiment is shown for GluN1/GluN2B $\left(B_{1,2}\right)$, GluN1/GluN2C $\left(C_{1,2}\right)$, and GluN1/GluN2D $\left(D_{1,2}\right)$. E) The mean \pm SEM fold change in steady-state amplitude is given for $(S)$-EU1180-154 (red) and $(R)$-EU1180-154 (blue). F) The fold change in weighted tau is given for $(S)$-EU1180-154 (red) and $(R)$-EU1180-154 (blue). Mean fitted time constants for all experiments are given in Table 2 (weighted tau) and Supplemental Table S3 (tauFAST, tausLow, relative contribution for tau $\left._{\mathrm{FAST}}\right){ }^{*} \mathrm{p}<0.05$, paired t-test. Power to detect an effect size of 1.5 for GluN2A-D was 0.98-0.99. 


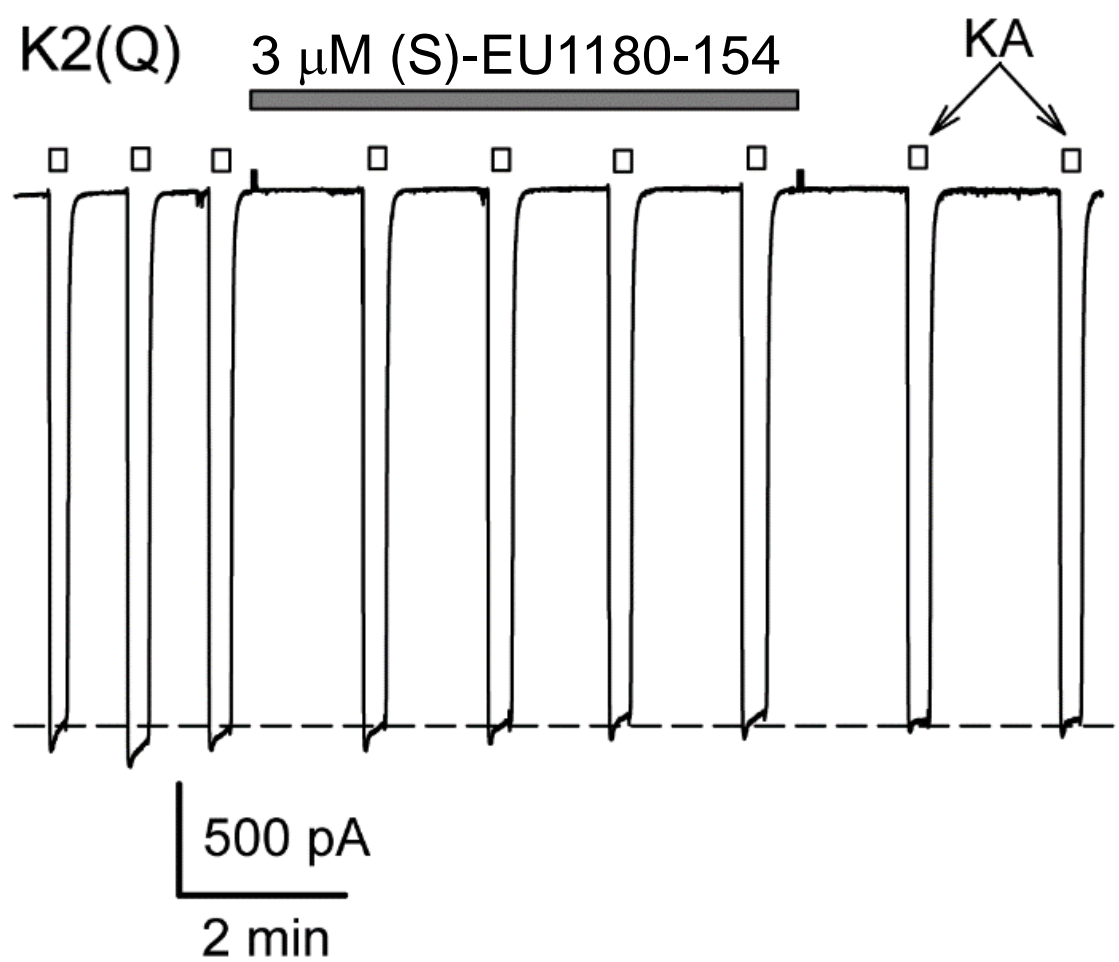

Supplemental Figure S6. (S)-EU1180-154 does not alter the response of GluK2 receptors. The whole cell current response from a representative HEK cell transiently expressing GluK2 unedited at the Q/R/N site and activated by kainate $(10 \mu \mathrm{M})$ in the absence and presence of $3 \mu \mathrm{M}(S)$-EU1180-154. $\mathrm{V}_{\text {HOLD }}$ was $-80 \mathrm{mV}$. Data are summarized in Supplemental Table S6. 
A<smiles>CNC(=O)N1N=C(c2ccc(N)c(Br)c2)c2cc3c(cc2CC1C)OCO3</smiles>

GYKI 53655

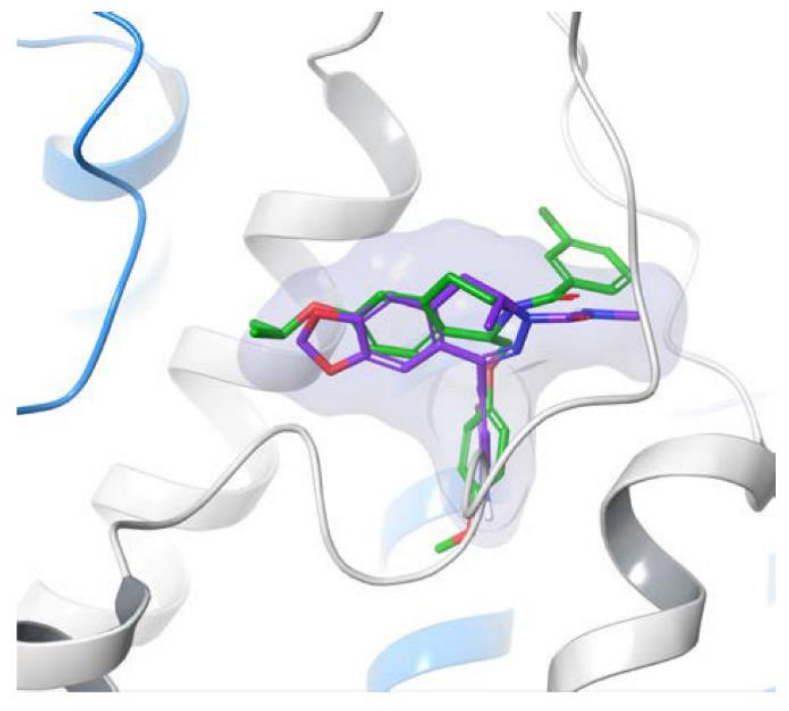

GluN1-pocket<smiles>COc1ccc(OCC2c3cc(OC(C)C)ccc3CCN2C(=O)c2cccc(Cl)c2)cc1</smiles>

EU1180-55

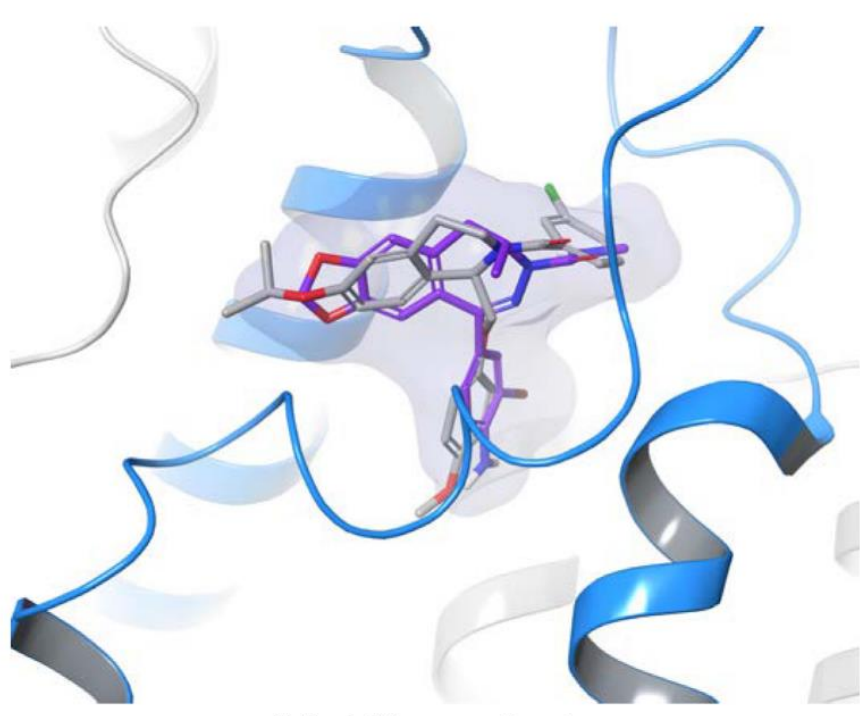

GluN2-pocket

Supplemental Figure S7. Overlay of GYKI 53655 and EU1180-55 enantiomers. A) The structures of GYKI 53655 and EU1180-55 are shown. B) An overlay of ( $S$ )-EU1180-55 and GYKI 53655 in the GluN1 pocket of a model of the GluN1/GluN2D NMDAR. C) An overlay of $(R)$-EU1180-55 and GYKI 53655 in the GluN2D pocket of the NMDAR. 
A GluN1-GluN2D 45\% Sequence Identity

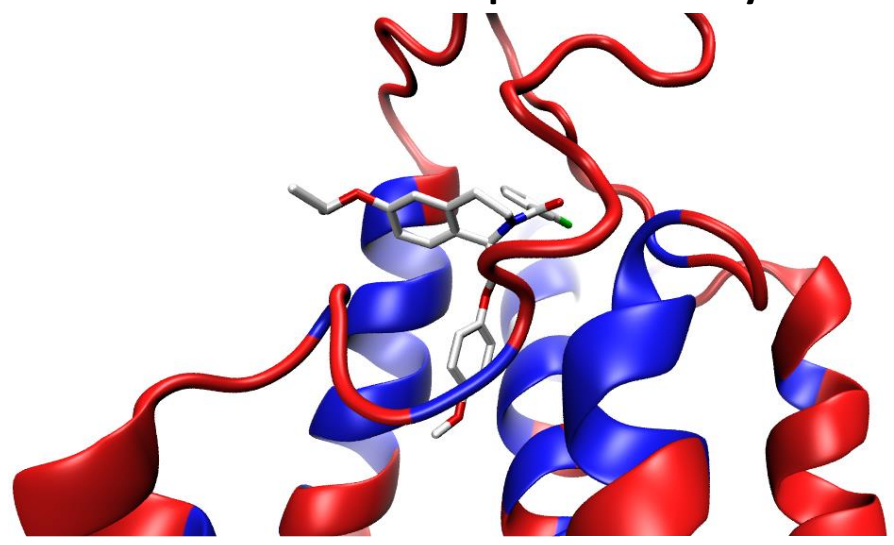

\section{GluN2A-D Sequence Identity (\%)}

$2 A$

2A 100 2B

2B 95.3 100 100

$2 \mathrm{C}$

2D

\section{B GluN1-GluN2D 70\% Sequence Similarity}
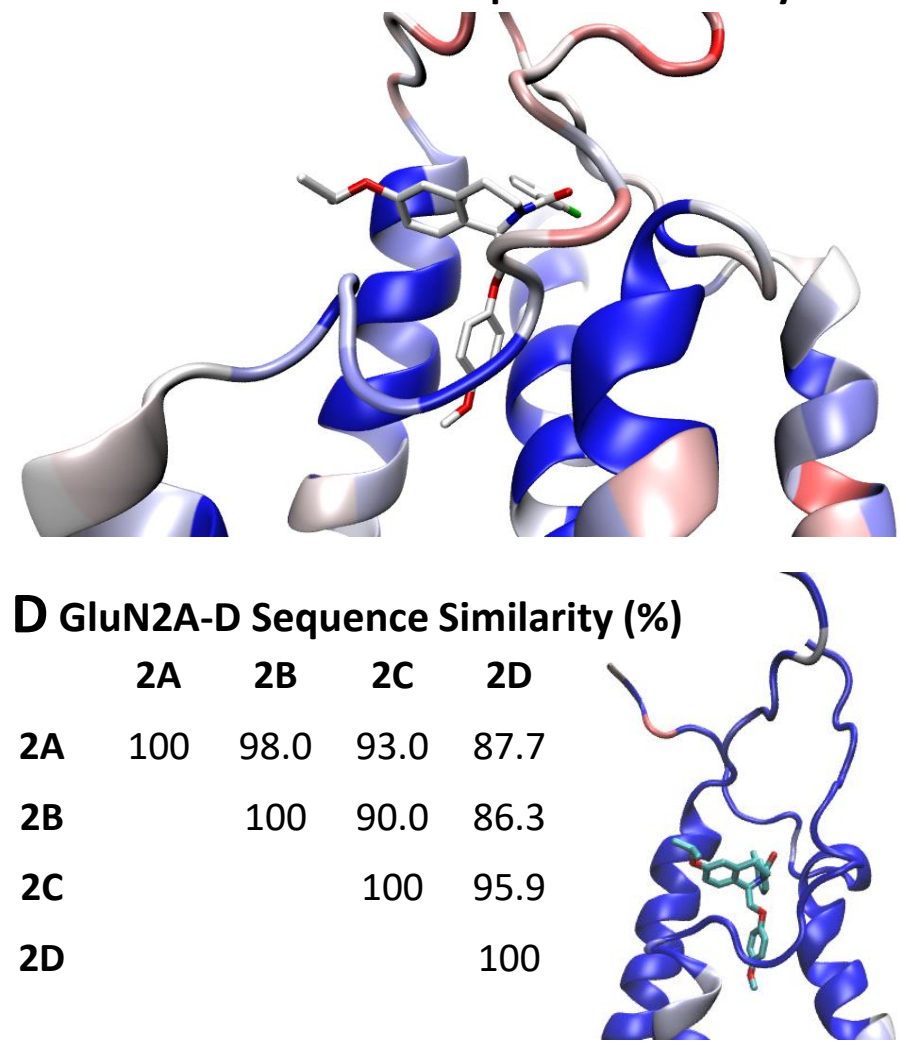

Figure S8: Comparison of sequence identity and similarity for the two pre-M1 pockets. A,B) We assessed the similarity of the binding pre-M1 pockets between GluN1 and GluN2D by performing a pocket overlay using 3D methods, and subsequently extracting the amino acid sequence that constitute the pockets, which included 70 residues within 10 Angstroms of the pocket. We performed a visual inspection to ensure that we included residues of interest and that residues correspond as closely as possible within 3D space. We used the resulting sequence to determine identity (A) and similarity (B) between the 2 pockets. We also assessed sequence identity (C) and similarity (D) for the residues across all four GluN2A-D subunits. For all panels, the main chains were colored using MultiSeq in VMD with the BLOSUM62 matrix. For sequencing identity $(\mathrm{A}, \mathrm{C})$, blue indicates the same residue and red a different residue. For sequence similarity $(\mathrm{B}, \mathrm{D})$, blue indicates the same residue, white a similar residue based on replacement frequencies in related proteins, and red a highly divergent residue. Residues comprising the GluN2D pocket (with GluN1 as partner) were: PFQL - (GluN1 557562, chain A), FAMIIVASYTANLAA - (GluN1 starting at 639, chain A), GTVSPSAFLEPYSP - (GluN2D starting at 570, chain B), LSYTANLAAFMIQEE - (GluN2D starting at 670, chain B), VMSSKLDIDNMAGVF - (GluN2D starting at 835 , chain B), NAPATLT - (GluN1 starting at 803, chain C). Residues comprising the GluN1 pocket (with the GluN2D pocket as partner) were: PYSV - (GluN2D starts at 580, chain B), FAVIFLASYTANLAA - (GluN2D starts at 639, chain B), PRSTLDSFMQPFQS - (GluN1 starts at 547, chain C), ASYTANLAAFLVLDR - (GluN1 starts at 645, chain C), NAPATLTFENMAGVF - (GluN1 starts 804, chain C), VMSSKLD - (GluN2D starts at 816, chain D). 


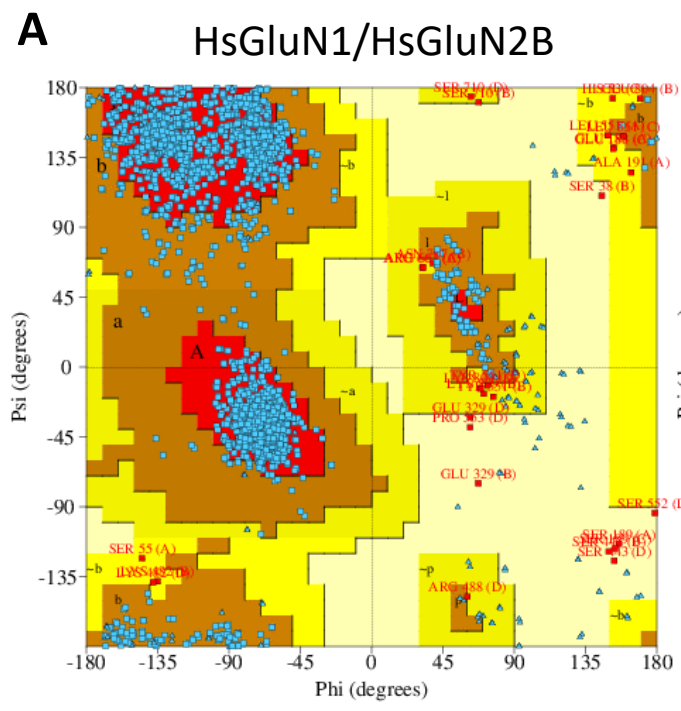

1. Ramachandran Plot statistics

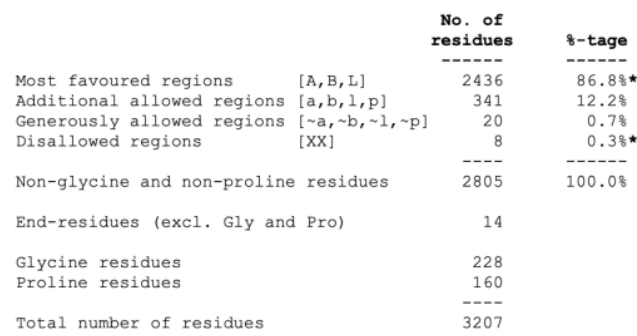

B HsGluN1/HsGluN2D

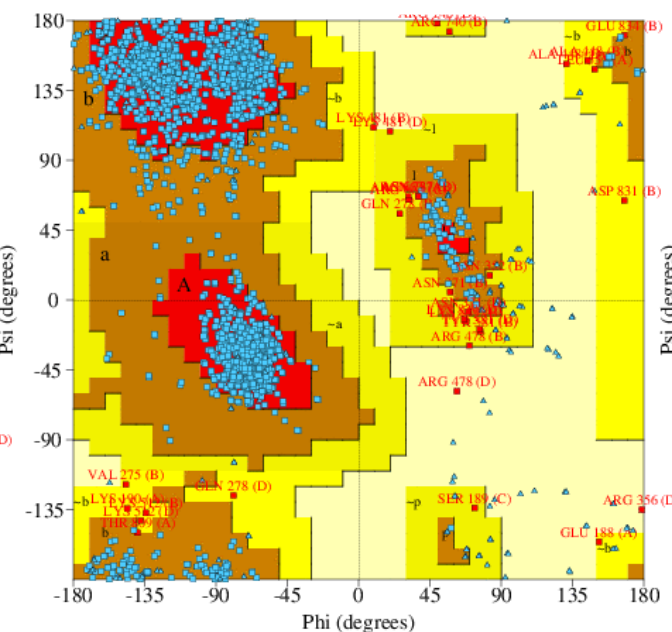

1. Ramachandran Plot statistics

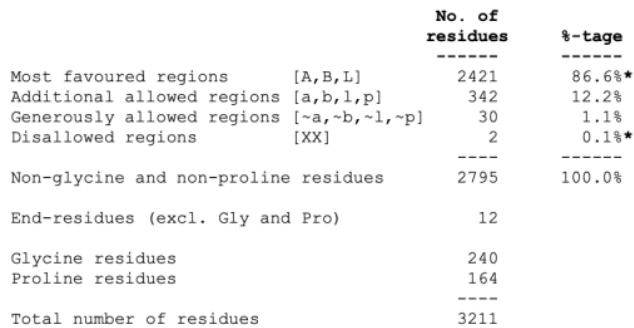

C HsGluN1/HsGluN2D GYKI

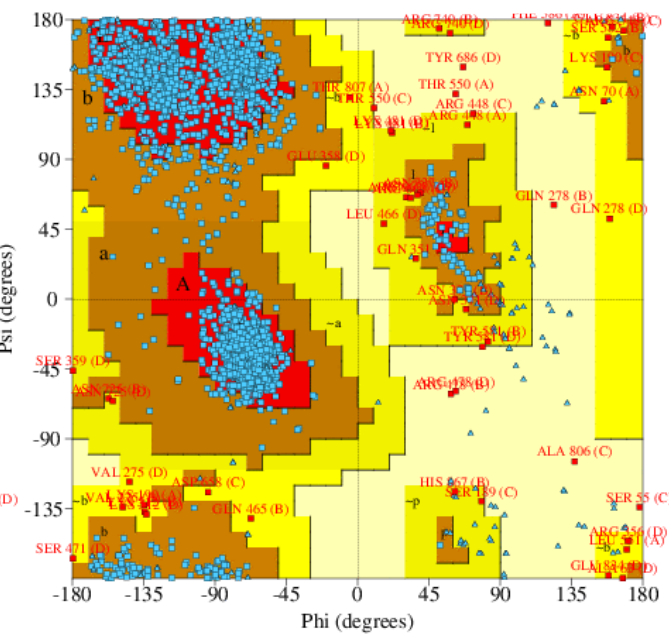

1. Ramachandran Plot statistics

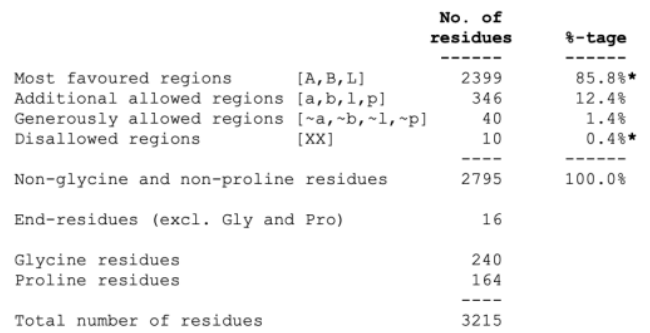

Supplemental Figure S9. The Ramachandran plots and associated statistics for models generated in this study. A) The Ramachandran plot of the human GluN1/GluN2B model in the non-active state. B) The Ramachandran plot for the human GluN1/GluN2D in the non-active state. C) The Ramachandran plot for human GluN1/GluN2D models containing GYKI 53665. Molpdf values from Modeller for human GluN1/GluN2B, GluN1/GluN2D, and GluN1GluN2DGYKI53655 ranged between 18856-20560, 19672-20834 and 41906-44085, respectively. 


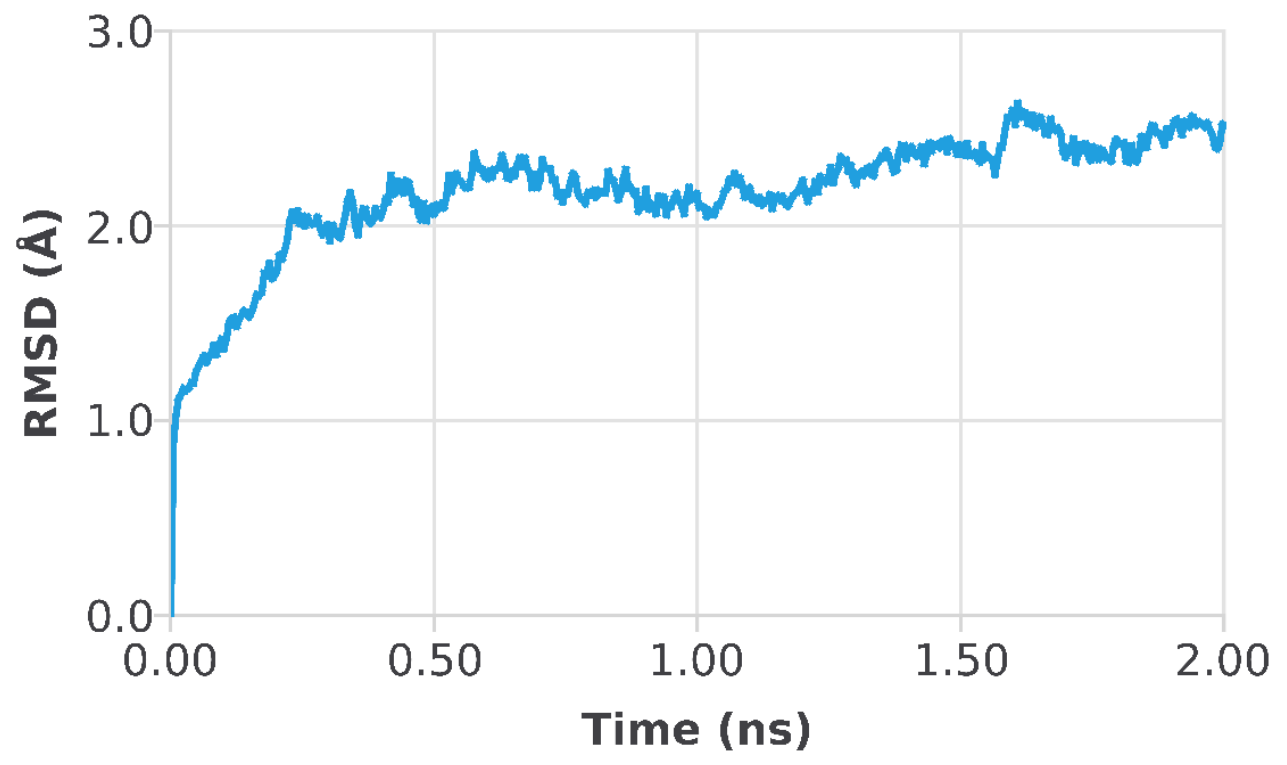

Supplemental Figure S10. Molecular dynamics RMSD. Backbone RMSD $(\AA)$ of the 2 ns molecular dynamics simulation of the human GluN1/GluN2D structure containing both the EU1180-55 enantiomers and truncated to remove the NTD. 


\section{References}

Grand, T., Abi Gerges, S., David, M., Diana, M.A., Paoletti, P. (2018) Unmasking GluN1/GluN3A excitatory glycine NMDA receptors Nat. Commun. 9, 4769. doi: 10.1038/s41467-019-08291-1.

Strong, K. L., Epplin, M. P., Bacsa, J., Butch, C. J., Burger, P. B., Menaldino, D. S., Traynelis, S. F., Liotta, D. C. (2017) The Structure-Activity Relationship of a Tetrahydroisoquinoline Class of N-Methyl-d-Aspartate Receptor Modulators That Potentiates GluN2B-Containing N-Methyl-d-Aspartate Receptors. J. Med. Chem. 60, 5556-5585.

Zhu, Z., Yi, F., Epplin, M.P., Liu, D., Summer, S.L., Mizu, R., Shaulsky, G., XiangWei, W., Tang, W., Burger, P.B., Menaldino, D.S., Myers, S.J., Liotta, D.C., Hansen, K.B., Yuan, H., Traynelis, S.F. (2020) Negative allosteric modulation of GluN1/GluN3 NMDA receptors. Neuropharmacology 176, 108117. doi:

10.1016/j.neuropharm.2020.108117. 